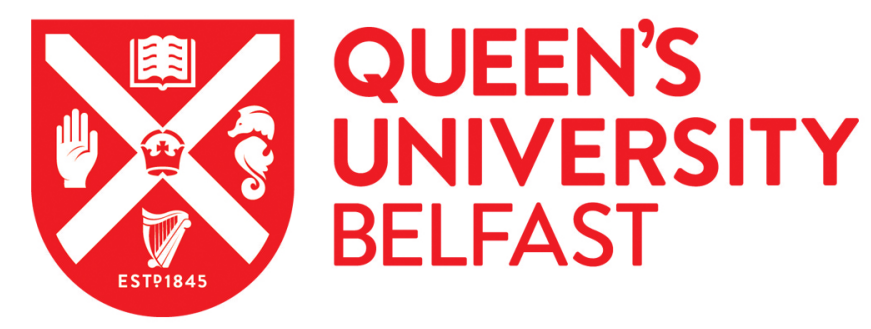

\title{
Isolation and Characterisation of a Halotolerant $\omega$-Transaminase from a Triassic Period Salt Mine and Its Application to Biocatalysis
}

Kelly, S. A., Megaw, J., Caswell, J., Scott, C. J., Allen, C. C. R., Moody, T. S., \& Gilmore, B. F. (2017). Isolation and Characterisation of a Halotolerant $\omega$-Transaminase from a Triassic Period Salt Mine and Its Application to Biocatalysis. ChemistrySelect, 2(30), 9783-9791. https://doi.org/10.1002/slct.201701642

Published in:

ChemistrySelect

Document Version:

Peer reviewed version

Queen's University Belfast - Research Portal:

Link to publication record in Queen's University Belfast Research Portal

Publisher rights

(C) 2017 Wiley-VCH Verlag GmbH \& Co. KGaA, Weinheim.

This work is made available online in accordance with the publisher's policies. Please refer to any applicable terms of use of the publisher.

\section{General rights}

Copyright for the publications made accessible via the Queen's University Belfast Research Portal is retained by the author(s) and / or other copyright owners and it is a condition of accessing these publications that users recognise and abide by the legal requirements associated with these rights.

Take down policy

The Research Portal is Queen's institutional repository that provides access to Queen's research output. Every effort has been made to ensure that content in the Research Portal does not infringe any person's rights, or applicable UK laws. If you discover content in the Research Portal that you believe breaches copyright or violates any law, please contact openaccess@qub.ac.uk. 
Isolation and Characterisation of a Halotolerant $\omega$-Transaminase from a Triassic Period Salt Mine and Its Application to Biocatalysis

Stephen A. Kelly ${ }^{[\mathrm{a}]}$, Julianne Megaw ${ }^{[\mathrm{a}]}$, Jill Caswell ${ }^{[\mathrm{b}]}$, Christopher J. Scott ${ }^{[\mathrm{c}]}$, Christopher C.R. Allen ${ }^{[\mathrm{d}]}$, Thomas S. Moody ${ }^{[\mathrm{b} / \mathrm{e}]}$, Brendan F. Gilmore ${ }^{*[\mathrm{a}]}$

\begin{abstract}
Chiral amines are valuable intermediates for the pharmaceutical industry, with up to $40 \%$ of current pharmaceuticals containing an amine functionality. However, their syntheses by conventional chemical methods often suffer from a number of key drawbacks. Transaminases (TAms) are pyridoxal phosphate (PLP) dependent enzymes capable of transferring an amine group to a prochiral ketone, offering a green and economically viable alternative to chiral amine production. Despite some high profile successes, TAms suffer from limited substrate scope and the ability to function under challenging conditions often required in reaction processes. Mining of untapped, extremophilic environments represents a viable approach in the search for novel enzymes. We report the cloning and expression of an $(S)$-selective $\omega$-TAm from a Halomonas sp. (Ad2-TAm), isolated from an extreme hypersaline environment formed during the Triassic era (circa 220 mya). Ad2-TAm exhibits an ability to convert a range of structurally diverse aldehyde and ketone substrates, with no decrease in conversion up to $1.5 \mathrm{M}(8.8 \%) \mathrm{NaCl}$. The enzyme is also tolerant to the presence of organic cosolvents up to $30 \%$ and accepts a range of amino donors. These characteristics make Ad2-TAm a promising candidate for industrial applications, whilst also highlighting the value of extreme environments as a source of novel enzymes for the pharmaceutical industry as a whole.
\end{abstract}

\title{
Introduction
}

Chiral amines are valuable and versatile building blocks for the pharmaceutical industry, with an estimated $40 \%$ of current pharmaceuticals containing an amine functionality. ${ }^{[1]}$ Current chemical syntheses of chiral amines suffer from a number of drawbacks, including the need for toxic transition metal catalysts and volatile organic 
solvents (VOCs), as well as insufficient stereoselectivity in a single step. ${ }^{[2]}$ These drawbacks have, in part, driven the rise of biocatalysis for the production of optically active amines. Biocatalytic approaches initially involved hydrolases, ${ }^{[3]}$ although other enzymes such as oxidases, lyases and transaminases (TAms) have been applied for this purpose, ${ }^{[4]}$ as well as dehydrogenases which have been reviewed recently. ${ }^{[5]}$

TAms are pyridoxal phosphate (PLP) dependent enzymes capable of transferring an amine group to a prochiral ketone, resulting in the formation of optically active amines. Despite high profile successes of TAm use in the pharmaceutical industry, namely the production of the antidiabetic drug sitagliptin, ${ }^{[6]}$ there is a growing need for new enzymes with improved capabilities. The application of TAms is often hampered by a restricted substrate scope, lack of tolerance to harsh reaction conditions and an inability of enzymes to accept bulky substrates without considerable protein engineering. ${ }^{[6-8]}$

Approaches to discover or create new TAms have involved both metagenomic approaches ${ }^{[9]}$ and directed evolution of existing enzymes. ${ }^{[10,11]}$ Another approach to overcome these challenges involves shifting the search for novel biocatalysts to previously untapped, extreme environments. The relatively understudied microbiomes of extreme environments represent a vast and exciting resource of novel organisms and biocatalysts. Extremophilic organisms are capable of functioning in conditions which render their mesophilic counterparts ineffective, such as high temperatures, extremes of $\mathrm{pH}$ and molar concentrations of salt. In this study we describe the isolation and characterisation of an $\omega$-TAm from a Triassic salt mine in Kilroot, Northern Ireland. The protein, annotated as adenosylmethionine-8amino-7-oxononanoate aminotransferase (Ad2-TAm),${ }^{[12]}$ was identified, cloned and expressed from the genome of a bacterium from the genus Halomonas, given the designation CSM-2. CSM-2 was isolated from a thalassohaline environment formed over 200 million years ago and has remained relatively undisturbed ever since. This affords an opportunity to effectively take a step back along the evolutionary timeline and examine the microbes of the past. Such an insight could aid in the discovery of ancestral biocatalysts with potentially unique substrate ranges when compared to their modern cousins. 
As well as tackling the issue of restricted substrate scope, biocatalysts from such an extreme hypersaline resource should prove capable of functioning under challenging reaction conditions often demanded by industrial processes.

\section{Experimental Section}

\section{Organism isolation and identification}

Organism CSM-2 was isolated by inoculating media containing peptone $(5 \mathrm{~g} / \mathrm{L})$, halite from Kilroot salt mine (10\%) and agar (1.5\%) with $100 \mu \mathrm{L}$ undiluted brine collected from a brine stream in within the mine. Colonies were restreaked to ensure purity and colony PCR was carried out to amplify the 16S rRNA gene for identification, using $25 \mu \mathrm{L}$ DreamTaq Green PCR Master Mix (2X) (Thermo Fisher Scientific, UK), $15 \mu \mathrm{L}$ PCR-grade water and $5 \mu \mathrm{L}$ each $(2.5 \mu \mathrm{M})$ of universal primers $27 \mathrm{~F}$ (5'-AGAGTTTGATCMTGGCTCAG-3') and $\quad 1492 \mathrm{R}$ $\left(5^{\prime}-\right.$ TACGGYTACCTTGTTACGACTT-3'). PCR conditions were set up with the following parameters: initial denaturation at $94{ }^{\circ} \mathrm{C}$ for $3 \mathrm{~min}, 30$ cycles of denaturation at $94{ }^{\circ} \mathrm{C}$ for $1 \mathrm{~min}$, annealing at $55^{\circ} \mathrm{C}$ for $1 \mathrm{~min}$ and extension at $72{ }^{\circ} \mathrm{C}$ for $1 \mathrm{~min}$, followed by a final single extension step at $72{ }^{\circ} \mathrm{C}$ for $10 \mathrm{~min}$. Agarose gel electrophoresis of PCR products ( $1 \%$ gel, $90 \mathrm{~V}, 45 \mathrm{~min})$ was used to determine size and purity of PCR amplicons. These were subsequently cleaned using a GeneJet PCR Purification kit (Thermo Fisher Scientific, UK) as per manufacturer's instructions and quantified using a Qubit ${ }^{\circledR}$ 2.0 Fluorometer (Invitrogen, UK). Concentration was adjusted to $10 \mu \mathrm{g} / \mathrm{mL}$ and sent for sequencing with Eurofins Genomics using the $27 \mathrm{~F}$ primer. The BLASTn function associated with the NCBI database was used to compare the resulting sequence to known sequences for identification.

\section{DNA extraction and PCR amplification of Ad2-TAm gene}


Genomic DNA was extracted from CSM-2 using GenElute ${ }^{\mathrm{TM}}$ Bacterial Genomic DNA Extraction kit (Sigma-Aldrich, UK) as per manufacturer's instructions. A sample of extracted DNA was sent to MR DNA Lab (Shallowater, TX, USA) for whole genome sequencing (WGS) using the Illumina MiSeq platform and the remainder retained for PCR. The assembled genome was annotated by uploading to the RAST server, and the Ad2-TAm gene was identified using the SEED Viewer tool and search term 'aminotransferase'. Forward (5'TTTTTTGAATTCATGACCTCGCCTGTCTGG-3') and reverse (5' TTTTTTCTCGAGCTAATGTTGCCCTGAGCTTTC-3') primers were designed specific to the gene sequence (Invitrogen, UK) with restriction sites included for EcoRI and XhoI respectively (highlighted in bold). $2.5 \mu \mathrm{L}(0.5 \mu \mathrm{M})$ of each primer along with $2 \mu \mathrm{L}$ genomic DNA were added to $10 \mu \mathrm{L} 5 \mathrm{x}$ Q5 reaction buffer, $1 \mu \mathrm{L}(0.2$ $\mathrm{mM}$ ) dNTPs, $0.5 \mu \mathrm{L}$ Q5 High-Fidelity Polymerase, $10 \mu \mathrm{L}$ 5x Q5 high GC enhancer, and nuclease-free water (to $50 \mu \mathrm{L}$ ) (all New England Biolabs Inc., MA, USA). PCR parameters were as follows: initial denaturation at $95{ }^{\circ} \mathrm{C}$ for $10 \mathrm{~min}, 35$ cycles of denaturation at $95{ }^{\circ} \mathrm{C}$ for $30 \mathrm{~s}$, annealing at $58{ }^{\circ} \mathrm{C}$ for $30 \mathrm{~s}$ and extension at $72{ }^{\circ} \mathrm{C}$ for $1 \mathrm{~min} 30 \mathrm{~s}$, followed by a final single extension step at $72{ }^{\circ} \mathrm{C}$ for $5 \mathrm{~min}$. Amplicons were checked on a $1 \%$ agarose gel $(90 \mathrm{~V}, 45 \mathrm{~min})$ and bands of desired length were excised and DNA extracted using a QIAquick Gel Extraction kit (Qiagen, Hilden, Germany) as per manufacturer's instructions.

\section{Preparation of pET28a+/Ad2-TAm vector}

$25 \mu \mathrm{L}$ pET28a+ vector and Ad2-TAm were each cut using restriction enzymes EcoRI-HF $(1 \mu \mathrm{L})$ and XhoI $(1 \mu \mathrm{L})$ (both New England Biolabs Inc., MA, USA) in a double digest with $3 \mu \mathrm{L}$ CutSmart buffer (NEB) for $1 \mathrm{~h}$ at $37{ }^{\circ} \mathrm{C} .1 \mu \mathrm{L}$ Alkaline Calf Intestinal Phosphatase (CIP) (NEB) was subsequently added to the pET28a+ mix and incubated for a further $1 \mathrm{~h}$ at $37^{\circ} \mathrm{C}$. Each sample was purified using a GeneJet PCR Purification kit (Thermo Fisher Scientific, UK) as per manufacturer's instructions. Restricted pET28a+ $(1 \mu \mathrm{L})$ and restricted Ad2-TAm gene $(3 \mu \mathrm{L})$ were mixed with T4 
DNA ligase buffer $(1 \mu \mathrm{L})$ and T4 DNA ligase $(1 \mu \mathrm{L})$ (both NEB), and adjusted to 10 $\mu \mathrm{L}$ with $\mathrm{ddH}_{2} \mathrm{O}$ followed by overnight incubation at $16{ }^{\circ} \mathrm{C}$.

\section{Transformation and expression of pET28a+/Ad2-TAm in Escherichia coli}

Following incubation, $2 \mu \mathrm{L}$ of ligation mix was added to $20 \mu \mathrm{L}$ One $\operatorname{Shot}^{\circledR}$ TOP10 Chemically Competent Escherichia coli cells and gently pipetted to mix. This was incubated on ice for $30 \mathrm{~min}$, heat shocked at $42{ }^{\circ} \mathrm{C}$ for $1 \mathrm{~min}$ before returning to ice for a further $2 \mathrm{~min}$. SOC medium was added $(200 \mu \mathrm{L}$; SOC $=0.5 \%$ yeast extract, $2 \%$ tryptone, $10 \mathrm{mM} \mathrm{NaCl}, 2.5 \mathrm{mM} \mathrm{KCL}, 10 \mathrm{mM} \mathrm{MgCl}_{2}, 10 \mathrm{mM} \mathrm{MgSO}_{4}$, and $20 \mathrm{mM}$ glucose per litre) and the mixture incubated at $37{ }^{\circ} \mathrm{C}$ with rotation for $1 \mathrm{~h}$. The mixture was plated on nutrient agar containing $50 \mu \mathrm{g} / \mathrm{mL}$ kanamycin sulphate and incubated overnight at $37{ }^{\circ} \mathrm{C}$. Cells were also transformed using the same method with empty pET28a+ vector for use as a negative control. Colony PCR using $5 \mu \mathrm{L}$ RedTaq Polymerase (NEB), forward and reverse primers $(0.5 \mu \mathrm{L}$ of each), and $\mathrm{ddH}_{2} \mathrm{O}$ (to $10 \mu \mathrm{L}$ ) was carried out using the same gene-specific primers and PCR parameters as with the initial amplification. Amplicons were visualized on a $1 \%$ agarose gel (90 V, $45 \mathrm{~min}$ ), sequenced by Eurofins Genomics, and aligned with the original gene sequence from WGS data using MEGA7 software. Individual colonies were picked and grown in $10 \mathrm{~mL}$ LB broth containing $50 \mu \mathrm{g} / \mathrm{mL}$ kanamycin sulphate overnight at $37{ }^{\circ} \mathrm{C}$. Plasmids were extracted using a QIAprep spin Miniprep kit (Qiagen, Hilden, Germany) following manufacturer's instructions. One Shot ${ }^{\mathbb{B}}$ BL21 DE3 Chemically Competent $E$. coli cells $(20 \mu \mathrm{L})$ were transformed with the recombinant plasmid $(2 \mu \mathrm{L})$ using the same protocol as before. Individual colonies were picked as before and used to inoculate $10 \mathrm{~mL}$ LB broth with $50 \mu \mathrm{g} / \mathrm{mL}$ kanamycin sulphate, followed by incubation overnight at $37{ }^{\circ} \mathrm{C}$ with rotation. This primary culture was used to inoculate $1 \mathrm{~L}$ LB broth with $50 \mu \mathrm{g} / \mathrm{mL}$ kanamycin sulphate, which was allowed to grow to early log phase (OD $\sim 0.6$ ) at $37{ }^{\circ} \mathrm{C}$ with rotation. This was induced using IPTG to a final concentration of $0.4 \mathrm{mM}$ and incubated at $20{ }^{\circ} \mathrm{C}$ overnight with rotation. Following incubation, the culture was pelleted via centrifugation, freeze-thawed at $-80{ }^{\circ} \mathrm{C}$, suspended in $0.1 \mathrm{M}$ potassium 


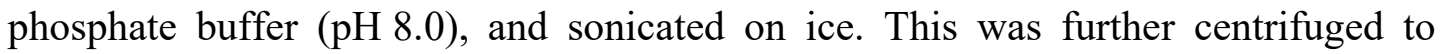
remove cell debris. For use as a cell-free extract, the supernatant (lysate) was decanted and lyophilized overnight. Alternatively, the lysate was clarified using 0.8 $\mu \mathrm{M}$ filters and purified as described below.

\section{His-tag-mediated purification of Ad2-TAm protein}

Clarified cell-free extract was purified by immobilized metal affinity chromatography (IMAC) using the N-terminal 6x His-tag encoded by the pET28a+ vector. An ÄKTA Prime Plus Liquid Chromatography System was used to load the clarate on a HisTrap ${ }^{\mathrm{TM}}$ HP $1 \mathrm{~mL}$ column (both GE Healthcare Life Sciences, UK) at a rate of $1 \mathrm{~mL} \mathrm{~min}^{-1}$. This was washed using buffer containing $50 \mathrm{mM} \mathrm{NaH}_{2} \mathrm{PO}_{4}, 300$ $\mathrm{mM} \mathrm{NaCl}, 20 \mathrm{mM}$ imidazole, made up to $1 \mathrm{~L}$ with $\mathrm{dH}_{2} \mathrm{O}$ and adjusted to $\mathrm{pH} 8.0$ with $\mathrm{NaOH}$. Purified protein was eluted in $1 \mathrm{~mL}$ fractions using buffer containing $50 \mathrm{mM}$ $\mathrm{NaH}_{2} \mathrm{PO}_{4}, 300 \mathrm{mM} \mathrm{NaCl}, 250 \mathrm{mM}$ imidazole made up to $1 \mathrm{~L}$ with $\mathrm{dH}_{2} \mathrm{O}$ and adjusted to $\mathrm{pH} 8.0$ with $\mathrm{NaOH}$.

\section{Expression and phylogenetic analysis}

Recombinant Ad2-TAm protein and empty vector controls were analysed via SDSPAGE using a NuPage ${ }^{\circledR} 4-12 \%$ Bis-Tris gel and NuPage ${ }^{\circledR}$ MES SDS running buffer, run at $200 \mathrm{~V}$ for $1 \mathrm{~h}$. Recombinant Ad2-TAm was also analysed using Western Blot, with a gel set up as above and transferred to a nitrocellulose membrane at $30 \mathrm{~V}$ for $2 \mathrm{~h}$ in buffer containing, per/L, tris $3.48 \mathrm{~g}$, glycine $14.42 \mathrm{~g}$, methanol $200 \mathrm{~mL}$, made up to $1 \mathrm{~L}$ with $\mathrm{dH}_{2} \mathrm{O}$. The resulting membrane was blocked using a solution of $5 \%$ skimmed milk in PBS at $37{ }^{\circ} \mathrm{C}(60 \mathrm{rpm})$ for $1 \mathrm{~h}$, rinsed thoroughly in PBS, and treated with 1 in 10,000 monoclonal anti-polyhistidine-peroxidase antibody solution (Sigma-Aldrich, UK) at room temperature $(60 \mathrm{rpm})$ for $1 \mathrm{~h}$. After rinsing with PBS, 


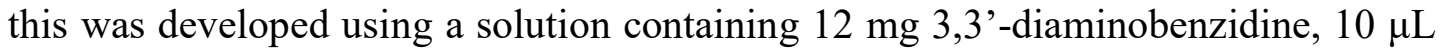

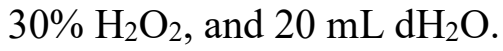

\section{Colorimetric screening assay using $o$-XDA as amino donor}

Using a protocol adapted from Green et al $(2014)^{[1]}, o-X D A 1(25 \mathrm{mM})$ and PLP (1 $\mathrm{mM}$ in potassium phosphate buffer, $100 \mathrm{mM}, \mathrm{pH} \mathrm{8.0)}$ and the substrate (final concentration of $5 \mathrm{mM}$ from an initial $50 \mathrm{mM}$ stock in DMSO) were added to a 96well deep well plate to give a total volume of $180 \mu \mathrm{L}$. The reaction was started by the addition of either $20 \mu \mathrm{L}$ rehydrated Ad2-TAm cell-free extract to a final working concentration of $20 \mathrm{mg} / \mathrm{mL}$, or $20 \mu \mathrm{L}$ purified protein at a final working concentration of $0.5 \mathrm{mg} / \mathrm{mL}$. A colour change from yellow to black denoted a positive result for TAm-catalyzed conversion.

\section{HPLC-based screening assay employing (S)-MBA as amino donor}

(S)-MBA 2 (25 mM) and PLP (1 mM in potassium phosphate buffer, $100 \mathrm{mM}, \mathrm{pH}$ 8.0 ), and the substrate (final concentration of $5 \mathrm{mM}$ from an initial $50 \mathrm{mM}$ stock in DMSO) were added to a 96-well deep well plate to give a total volume of $180 \mu \mathrm{L}$. For assays employing sodium pyruvate and $\alpha$-ketoglutaric acid, stock concentrations of these substrates were prepared in water due to poor solubility in DMSO. These reaction mixes were then supplemented with an appropriate amount of DMSO. The reaction was initiated by the addition of $20 \mu \mathrm{L}$ rehydrated Ad2-TAm cell-free extract to a final working concentration of $20 \mathrm{mg} / \mathrm{mL}$. Purified Ad2-TAm was also tested for ability to convert substrates using $20 \mu \mathrm{L}$ purified protein at a final working concentration of $0.5 \mathrm{mg} / \mathrm{mL}$. After incubation for $16 \mathrm{~h}$ at $30^{\circ} \mathrm{C}$ and $1200 \mathrm{rpm}$, the reaction was quenched with $800 \mu \mathrm{L} 62.5 \%$ acetonitrile and denatured protein was removed by centrifugation. $200 \mu \mathrm{L}$ of supernatant was removed for analysis by HPLC using a Kinetex 5u C18 100A column (50 x 4.6 mm) and an Agilent 1260 Infinity model, with detection of acetophenone 4 coproduct at $240 \mathrm{~nm}$. Product 
formation in the assays employing purified protein was also detected using a diode array detector (DAD) at $10 \mathrm{~nm}$ intervals from wavelengths $210 \mathrm{~nm}$ to $270 \mathrm{~nm}$. The concentration of acetophenone coproduct formation was determined over $8 \mathrm{~min}$ using a gradient of 5-50\% organic solvent (where $\mathrm{A}=\mathrm{dH}_{2} \mathrm{O}$ with $0.1 \% \mathrm{H}_{3} \mathrm{PO}_{4}$ and $\mathrm{B}$ $=$ acetonitrile with $0.1 \% \mathrm{H}_{3} \mathrm{PO}_{4}$ ). Acetophenone eluted at a retention time of $5.9 \mathrm{~min}$. Assays using both Ad2-TAm and vector only controls were carried out in triplicate for each substrate, with an average taken for each and values for negative control subtracted from Ad2-TAm values.

\section{HPLC-based screening assay employing cinnamaldehyde as substrate}

Amino donor $(25 \mathrm{mM})$ and PLP $(1 \mathrm{mM}$ in potassium phosphate buffer, $100 \mathrm{mM}, \mathrm{pH}$ 8.0) and cinnamaldehyde 9 (final concentration of $5 \mathrm{mM}$ from an initial $50 \mathrm{mM}$ stock in DMSO) were added to a 96-well deep well plate to give a total volume of $180 \mu \mathrm{L}$. The reaction was started by the addition of $20 \mu \mathrm{L}$ rehydrated Ad2-TAm cell-free extract to a final working concentration of $20 \mathrm{mg} / \mathrm{mL}$. After incubation for $16 \mathrm{~h}$ at $30{ }^{\circ} \mathrm{C}$ and $1200 \mathrm{rpm}$, the reaction was quenched with $800 \mu \mathrm{L} 62.5 \%$ acetonitrile and denatured protein was removed by centrifugation. $200 \mu \mathrm{L}$ of supernatant was removed for analysis by HPLC using a Kinetex 5u C18 100A column (50 x $4.6 \mathrm{~mm})$ with detection at $210 \mathrm{~nm}$. The concentration of cinnamyl amine $\mathbf{2 0}$ product formation was determined over 8 min using a gradient of $5-50 \%$ organic solvent (where $\mathrm{A}=$ $\mathrm{dH}_{2} \mathrm{O}$ with $0.1 \% \mathrm{H}_{3} \mathrm{PO}_{4}$ and $\mathrm{B}=$ acetonitrile with $\left.0.1 \% \mathrm{H}_{3} \mathrm{PO}_{4}\right)$. Cinnamyl amine eluted at a retention time of $2.8 \mathrm{~min}$. Assays using both Ad2-TAm and vector only controls were carried out in triplicate for each amino donor, with an average taken for each and values for negative control subtracted from Ad2-TAm values.

\section{Evaluation of enzyme performance under varying reaction parameters}

(S)-MBA 2 (25 mM) and PLP (1 mM in potassium phosphate buffer, $100 \mathrm{mM}, \mathrm{pH}$ 8.0 unless changed to assess effect of changing $\mathrm{pH}$ ), and benzaldehyde (final 
concentration of $5 \mathrm{mM}$ from an initial $50 \mathrm{mM}$ stock in DMSO) were added to a 96well deep well plate to give a total volume of $180 \mu \mathrm{L}$. The reaction was initiated by the addition of $20 \mu \mathrm{L}$ rehydrated Ad2-TAm cell-free extract to a final working concentration of $20 \mathrm{mg} / \mathrm{mL}$. After incubation for $16 \mathrm{~h}$ at $30^{\circ} \mathrm{C}$ (unless changed to assess effect of changing temperature) and $1200 \mathrm{rpm}$, the reaction was quenched with $800 \mu \mathrm{L} 62.5 \%$ acetonitrile and denatured protein was removed by centrifugation. 200 $\mu \mathrm{L}$ of supernatant was removed for analysis by HPLC using a Kinetex 5u C18 100A column (50 x $4.6 \mathrm{~mm})$ and an Agilent 1260 Infinity model, with detection of acetophenone 4 coproduct at $240 \mathrm{~nm}$. The concentration of acetophenone coproduct formation was determined over 8 min using a gradient of 5-50\% organic solvent (where $\mathrm{A}=\mathrm{dH}_{2} \mathrm{O}$ with $0.1 \% \mathrm{H}_{3} \mathrm{PO}_{4}$ and $\mathrm{B}=$ acetonitrile with $0.1 \% \mathrm{H}_{3} \mathrm{PO}_{4}$ ). Acetophenone eluted at a retention time of 5.9 min. Assays using both Ad2-TAm and vector only controls were carried out in triplicate for each substrate, with an average taken for each and values for negative control subtracted from Ad2-TAm values.

To assess the effect of temperature on enzyme performance, assays were set up as described above but incubated at different temperatures, ranging from $20-45^{\circ} \mathrm{C}$.

To assess the effect of changing $\mathrm{pH}$ on enzyme performance, assays were set up using a universal buffer ${ }^{[2]}$ in place of phosphate buffer. This contained $25 \mathrm{mM}$ citric acid, $25 \mathrm{mM} \mathrm{KH} \mathrm{PO}_{4}, 25 \mathrm{mM}$ Tris, $12.5 \mathrm{mM} \mathrm{Na}_{2} \mathrm{~B}_{4} \mathrm{O}_{7}$ and $25 \mathrm{mM} \mathrm{KCl}$, adjusted using $\mathrm{NaOH}$, with $\mathrm{pH}$ values from $\mathrm{pH} 6.0$ to 11.0 investigated.

To assess the effect of organic solvents on enzyme performance, more concentrated stock solutions of potassium phosphate buffer $(\mathrm{pH} \mathrm{8.0)}$ were prepared to reduce the aqueous volume in the reaction accordingly, with PLP concentrations also adjusted in buffer solutions accordingly. Once diluted by the required amount of organic solvent, the overall concentrations of potassium phosphate buffer $(\mathrm{pH} 8.0)$ and PLP in solution remained at $100 \mathrm{mM}$ and $1 \mathrm{mM}$, as before. Concentrations of organic solvents investigated ranged from $0-30 \%$.

To assess the effect of increasing salt concentration on enzyme performance, potassium phosphate buffer stock solutions were prepared containing the required amounts of $\mathrm{NaCl}$ and $\mathrm{KCl}$ respectively (warmed gently where necessary to dissolve fully). These were prepared so that the dilutive effect of other reaction constituents ensured the appropriate overall salt concentration in the assay. Buffer $\mathrm{pH}$ was 
adjusted using small amounts of $\mathrm{NaOH}$ to account for the addition of salt. Salt concentrations assessed ranged from $0-2.5 \mathrm{M}$ for both $\mathrm{NaCl}$ and $\mathrm{KCl}$.

In assessing the effect of increased volume of reaction, (S)-MBA $2(25 \mathrm{mM})$ and PLP (1 mM in potassium phosphate buffer, $100 \mathrm{mM}, \mathrm{pH} 8.0$ ) and benzaldehyde 3 (final concentration of $5 \mathrm{mM}$ from an initial $50 \mathrm{mM}$ stock in DMSO) were added to a sterile $250 \mathrm{~mL}$ conical flask to give a total volume of $90 \mathrm{~mL}$. The reaction was started by the addition of $10 \mathrm{~mL}$ rehydrated Ad2-TAm cell-free extract to a final working concentration of $20 \mathrm{mg} / \mathrm{mL}$. After incubation for $16 \mathrm{~h}$ at $30^{\circ} \mathrm{C}$ and $100 \mathrm{rpm}$, the reaction mixture was transferred to a sterile $1 \mathrm{~L}$ flask and the reaction quenched with $400 \mathrm{~mL} 62.5 \%$ acetonitrile. Denatured protein was removed by centrifugation. $200 \mu \mathrm{L}$ of supernatant was removed for analysis by HPLC using a Kinetex 5u C18 $100 \mathrm{~A}$ column $(50 \times 4.6 \mathrm{~mm})$ with detection at $240 \mathrm{~nm}$. The concentration of acetophenone product formation was determined over 8 min using a gradient of 0 $50 \%$ organic solvent (where $\mathrm{A}=\mathrm{dH}_{2} \mathrm{O}$ with $0.1 \% \mathrm{H}_{3} \mathrm{PO}_{4}$ and $\mathrm{B}=$ acetonitrile with $0.1 \% \mathrm{H}_{3} \mathrm{PO}_{4}$ ) with subtraction of empty vector negative control. The acetophenone product eluted at a retention time of $5.9 \mathrm{~min}$.

\section{Determination of specific activity}

(S)-MBA 2 (25 mM) and PLP (1 $\mathrm{mM}$ in universal buffer (as above) $\mathrm{pH} 9.0$ ), and benzaldehyde 3 (final concentration of $5 \mathrm{mM}$ from an initial $50 \mathrm{mM}$ stock in DMSO) were added to a $1.5 \mathrm{~mL}$ microtube to give a total volume of $180 \mu \mathrm{L}$. The reaction was initiated by the addition of $20 \mu \mathrm{L}$ rehydrated Ad2-TAm cell-free extract to a final working concentration of $1 \mathrm{mg} / \mathrm{mL}$. Reactions were quenched with $800 \mu \mathrm{L}$ $62.5 \%$ acetonitrile at regular time intervals and denatured protein was removed by centrifugation. $200 \mu \mathrm{L}$ of supernatant was removed for analysis by HPLC using an $\mathrm{XBridge}^{\circledR} \mathrm{C} 183.5 \mu \mathrm{m}$ column $(100 \times 4.6 \mathrm{~mm})$ and an Agilent 1260 Infinity model, with detection of acetophenone 4 coproduct at $240 \mathrm{~nm}$. The concentration of acetophenone coproduct formation was determined over 10 min using a gradient of $5-50 \%$ organic solvent (where $\mathrm{A}=\mathrm{dH}_{2} \mathrm{O}$ with $0.1 \% \mathrm{H}_{3} \mathrm{PO}_{4}$ and $\mathrm{B}=$ acetonitrile with $0.1 \% \mathrm{H}_{3} \mathrm{PO}_{4}$ ). Acetophenone eluted at a retention time of $9.0 \mathrm{~min}$. Assays using both 
Ad2-TAm and vector only controls were carried out in triplicate, with an average taken for each and values for negative control subtracted from Ad2-TAm values. Ad2-TAm concentration in cell-free extract was determined using a combination of a Qubit $^{\circledR}$ 2.0 Fluorometer (Invitrogen, UK) and SDS-PAGE densitometry. 


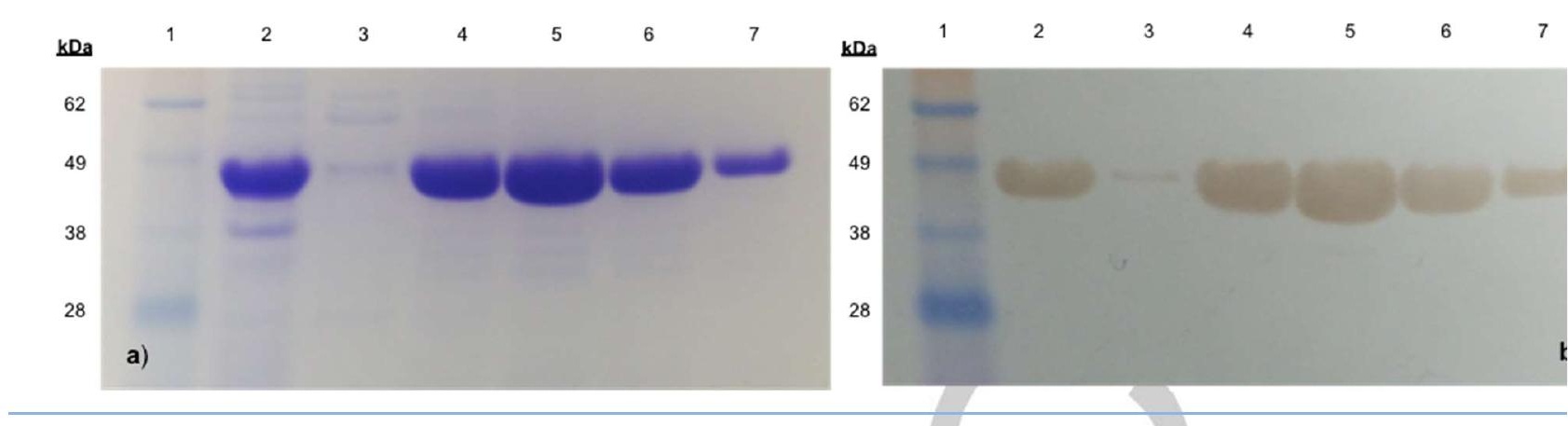

Fig. 1. SDS-PAGE a) and Western Blot b) of pre-purified clarate (well 2) and Ad2-TAm fractions, purified by His-tagged prote purification (wells 3-7), alongside SeeBlue $囚$ Plus2 Protein Standard (well 1).

\section{Results and Discussion}

\section{Organism identification and gene selection}

The organism, from which the TAm enzyme was cloned and expressed, was isolated from a brine sample from Kilroot salt mine and given the designation CSM-2 (This Whole Genome Shotgun project has been deposited at DDBJ/ENA/GenBank under the accession NBYR00000000. The version described in this paper is version NBYR01000000). Using the Basic Local Alignment Search Tool nucleotide (BLASTn) function ${ }^{[13]}$ of the National Center for Biotechnology Information (NCBI) database, ${ }^{[14]}$ the organism was found to be a member of the genus Halomonas, with the closest neighbour deemed to be Halomonas janggokensis M24 (99\% similarity).

On uploading the assembled contigs from WGS data to the Rapid Annotations using Subsystems Technology (RAST) server, ${ }^{[12]}$ the subsystems search tool revealed 29 results using the search term 'aminotransferase'. The gene 'adenosylmethionine8-amino-7-oxononanoate aminotransferase' was selected based on PLP fold type (Fold type I) and TAm class (Class III) known to be industrially relevant. ${ }^{[15]}$ The gene was $1284 \mathrm{bp}$ in length and the corresponding protein was given the designation Ad2-TAm. 


\section{Purification and expression analysis}

SDS-PAGE analysis following purification showed the formation of a $47 \mathrm{kDa}$ protein (Fig. 1A.), commensurate with a gene length of 1284 bp. Analysis using Western Blotting further confirmed the presence of the desired protein, using the $6 \mathrm{x}$ His-tag encoded by the pET28a+ vector in combination with an N-terminal antipolyhistidine-peroxidase antibody (Fig. 1B.).

\section{Phylogenetic analysis and alignment with other TAms}

A number of other TAms were cloned and expressed from bacterial isolates using the same approach as with Ad2-TAm (Supplementary Fig. 1). These proteins were not expressed in soluble form and therefore did not possess any biocatalytic activity. Attempts to solubilise these proteins with urea followed by refolding in saltcontaining buffer were unsuccessful. Varying expression conditions by reducing temperature and changing IPTG concentration was also tried without success. The amino acid sequences for these genes, relative to that of Ad2-TAm, are shown in Fig. 2, as well as a number of sequences from TAms of known organisms: Vibrio fluvialis (Vf-TAm) ${ }^{[16]}$ Pseudomonas putida (Pp-TAm) ${ }^{[17]}$ Chromobacterium violaceum $(\mathrm{CV} \text {-TAm })^{[18]}$ and Halomonas sp. (Hs-TAm). ${ }^{[19]}$ A neighbour-joining tree was generated using MEGA $7,{ }^{[20]}$ with bootstrap values calculated based on 1000 replicates. Using protein BLAST (BLASTp) function ${ }^{[13]}$ associated with the NCBI database, the closest neighbour to Ad2-TAm was determined to be a TAm from Halomonas sp., with a sequence similarity of $89 \%$. Ad2-TAm shared relatively low homology with

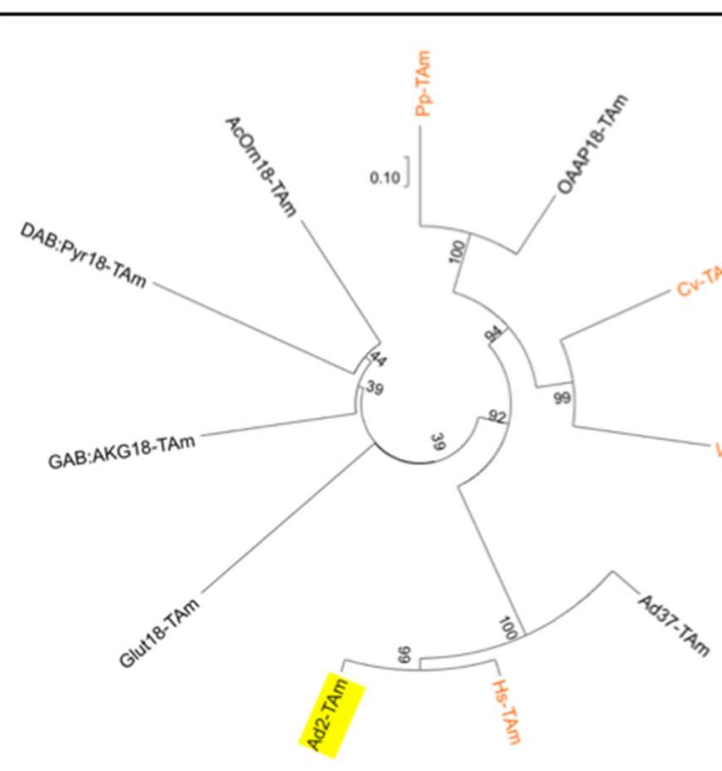

Fig. 2. Amino acid sequences of TAm genes from wh genomes (including Ad2-TAm - highlighted in yellow) and number of TAms from identified species (Pp-TAm, CV-TA Vf-TAm and Hs-TAm - shown in red) were used to create neighbour-joining tree (bootstrap values calculated from 10 replicates). 
commonly employed TAms (Vf-TAm - 28\%, Pp-TAm - 28\%, Cv-TAm - 30\%).

Despite the low level of homology, many critical residues were conserved across all sequences (Fig. 3). These include a tryptophan residue at position 60 (W60), which is key for substrate specificity; a tyrosine residue at position 153 (Y153), which allows for hydrogen bonding of a hydroxyl group to the phosphate group of PLP; and a lysine residue at position 288 (K288), critical for Schiff base formation. ${ }^{[21]}$

\section{Screening purified Ad2-TAm for ability to convert substrates}

Purified Ad2-TAm was tested for the ability to convert substrates using a selection of compounds (shown with an asterisk in Fig. 4) and $o$-xylylenediamine (o-XDA) 1 as amino donor (Scheme 1A). Aldehydes, aromatic ketones, and a ketose were accepted by the purified enzyme, demonstrating the versatility of Ad2-TAm's substrate range (Fig. 5). In each case, the same imidazole-containing buffer used to elute Ad2-TAm from the purification column was used as a negative control (full triplicate results shown in Supplementary Fig. 2). 


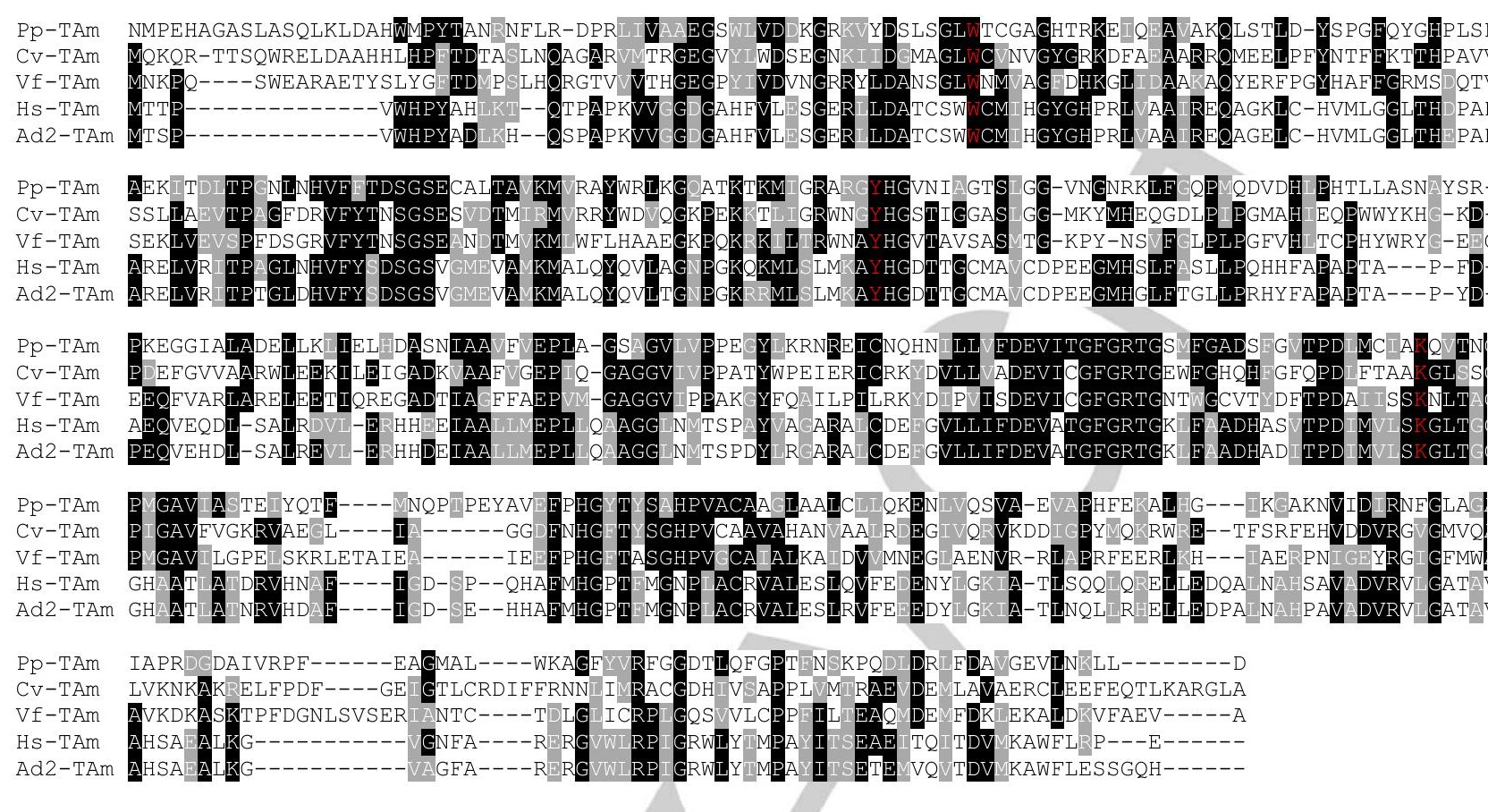

Fig. 3. Multiple alignment of amino acid sequence of Ad2-TAm with a number of TAms from identified species (Pp-TAm, Cv-TAm, $\mathrm{TAm}$ and $\mathrm{Hs}$-TAm). Key residues for activity and substrate specificity are conserved across all sequences, including Trp60, Tyr153 Lys288 (highlighted in red).

(S)-methylbenzylamine ((S)-MBA) 2 was also used as an amino donor in a HPLC-based assay (Scheme 1B.), employing benzaldehyde $\mathbf{3}$ as substrate. The resultant HPLC separation was observed over a range of wavelengths, with the more hydrophilic amino donor eluted early in the run with a retention time $(\mathrm{RT})$ of $1.5 \mathrm{~min}$, and the more hydrophobic acetophenone product (RT $5.9 \mathrm{~min}$ ) and remaining benzaldehyde substrate (RT $5.1 \mathrm{~min})$. This reaction proceeded with a $26 \%$ conversion.

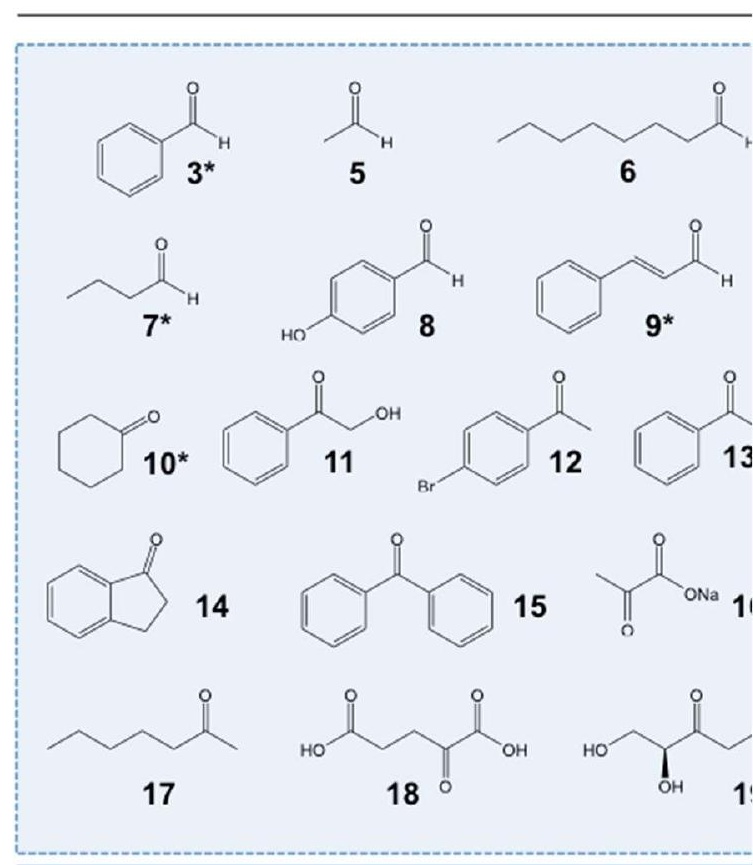

Screening Ad2-TAm cell-free extract for ability to convert substrates 
Purification of the His-tagged protein allowed for characterisation and basic testing of the pure, expressed enzyme's ability to convert substrates. However, lack of stability associated with the purified protein led to difficulties in scale-up and increasing the enzyme concentration in the reaction. A number of approaches including lyophilisation and dialysis were attempted in order to overcome this issue, but led to precipitation of the protein on dialysis or resuspension. With the use of empty vector $(\mathrm{pET} 28 \mathrm{a}+)$ controls, the cell-free extract was deemed to represent a more suitable approach to characterising the ability of Ad2-TAm to convert different substrates. It was possible to lyophilize and resuspend Ad2-TAm as a cell-free extract, allowing for greater enzyme loading in assays. This provided a more accurate reflection of the capabilities of Ad2-TAm as a biocatalyst.

\section{Colorimetric assay using $o$-XDA as amino donor}

The colorimetric assay (Scheme 1A.) once again demonstrated the versatility of Ad2-TAm as a biocatalyst, with the enzyme able to accept a diverse range of substrates. As observed in Fig. 7, both aromatic and aliphatic aldehydes and ketones were aminated, whilst no colour change was observed with the vector only control in each case (Supplementary Fig. 3). This broad substrate acceptance is typical of Class III TAm enzymes, ${ }^{[9,22-24]}$ and represents one of the key advantages of using this particular group for chiral amine synthesis.

This assay is useful as an initial visual screen for active TAms, but is limited by its high level of sensitivity, often producing positive results when no substrate is added to the reaction mixture, with PLP acting as amino acceptor. Despite this, there appears to be a broad correlation between the intensity of the black colour formed at $30 \mathrm{~min}$ (Fig. 7) and those substrates which were best converted at $16 \mathrm{~h}$, as shown by the HPLC-based screening assay (Table 1.). It is worth noting other

Fig. 4 - Substrates screened with assay A (using (S)-N as an amino donor and HPLC detection of acetophenone $240 \mathrm{~nm}$ ) and $C$ (using o-XDA as an amino donor observing formation of coloured precipitate to denote $\mathrm{TH}$ colorimetric assays which have been developed catalyzed substrate conversion). Those substrates use testing of IMAC-purified Ad2-TAm are shown with recently for high-throughput screening of TAms may asterisk. 
circumvent such issues. ${ }^{[25]}$

\section{HPLC-based screening assay using (S)-MBA as amino donor}

The same substrates used in the colorimetric assay were tested using a HPLC-based assay with $(S)$-MBA 2 as amino donor (Scheme 1B.). Assays were carried out in triplicate, with results for vector only controls subtracted in each case. Acetophenone 4 product formation, detected a $240 \mathrm{~nm}$, was used to determine conversion (\%) for each substrate. Ad2-TAm performed well with many aldehyde substrates, with good conversion of both aliphatic and aromatic aldehydes (benzaldehyde 3 55\%, acetaldehyde 5 52\%). Increases in substrate acyl chain length led to a reduction in conversion (octanal $622 \%$ vs. butyraldehyde $749 \%$ ), consistent with observations noted in the limited existing literature. ${ }^{[9]}$ Similar results were observed with the addition of side groups to the benzyl ring of aromatic aldehydes (benzaldehyde 55\% vs. 4-hydroxybenzaldehyde 8 and cinnamaldehyde 9, 39\% and 36\% respectively). Aromatic ketones followed a similar pattern, with simpler structures showing higher levels of amination than their more complex counterparts (cyclohexanone $\mathbf{1 0} 49 \%$ vs. 2hydroxyacetophenone 11 39\%, 4-bromoacetophenone $1212 \%$ and propiophenone 13 \%). Bicyclic ketones such as the steroid building block 1-indanone 14 (7\% conversion) and the biphenyl ketone benzophenone 15 (2\% conversion) were poorly accepted by $\mathrm{Ad} 2-$ TAm, most likely due to the steric constraint afforded

Scheme 1. A. o-XDA screening assay performed aga multiple substrates. Reaction conditions: o-XDA $25 \mathrm{r}$ substrate $5 \mathrm{mM}$, PLP $1 \mathrm{mM}$, potassium phosphate bu $\mathrm{pH} 8.0,100 \mathrm{mM}$, enzyme as cell-free extract $(20 \mathrm{mg} / \mathrm{mL}$ His-tagged purified protein $(0.5 \mathrm{mg} / \mathrm{mL}), 16 \mathrm{~h}, 30$ $1200 \mathrm{rpm}$. B. (S)-MBA screening assay performed aga multiple substrates. Reaction conditions: (S)-MBA 25 r substrate $5 \mathrm{mM}$, PLP $1 \mathrm{mM}$, potassium phosphate buffer, $8.0,100 \mathrm{mM}$, enzyme as cell-free extract $(20 \mathrm{mg} / \mathrm{mL})$ or tagged purified protein $(0.5 \mathrm{mg} / \mathrm{mL}), 16 \mathrm{~h}, 30{ }^{\circ} \mathrm{C}, 1200 \mathrm{r}$ C. Cinnamaldehyde screening assay performed u multiple amino donors. Reaction conditions: amino dc $25 \mathrm{mM}$, cinnamaldehyde $5 \mathrm{mM}$, PLP $1 \mathrm{mM}$, potass phosphate buffer, pH 8.0, $100 \mathrm{mM}$, enzyme as cellextract $(20 \mathrm{mg} / \mathrm{mL})$ or His-tagged purified pro $(0.5 \mathrm{mg} / \mathrm{mL}), 16 \mathrm{~h}, 30{ }^{\circ} \mathrm{C}, 1200 \mathrm{rpm}$. by their bulky substituents. Aliphatic ketones showed poor conversion yields, (sodium pyruvate 16 4\%, 2-heptanone 17 7\%, $\alpha$-ketoglutaric acid 18 6\%), whilst Ad2-TAm displayed a reasonable ability to convert the ketose sugar L-erythrulose 19 (25\% conversion). It is notable that Ad2-TAm exhibited greater conversion of aldehydes than ketone substrates, which can be attributed to the greater reactivity of aldehydes given the greater electrophilicity of their carbonyl 


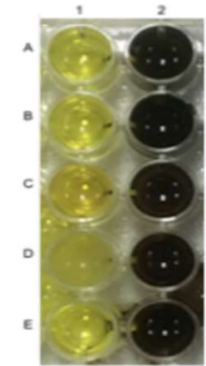

group vs. ketones. ${ }^{[22]}$ Percentage conversion for all substrates tested are shown in Table 1. When no substrate was used in the reaction conversion values were $<1 \%$.

Specific activity was determined as $0.11 \mathrm{U} / \mathrm{mg}$ for 3 . One unit is defined as the amount of enzyme that produces $1 \mu \mathrm{mol}$ of acetophenone in $1 \mathrm{~min}$. Although benzaldehyde may not be the cognate substrate for Ad2-TAm in

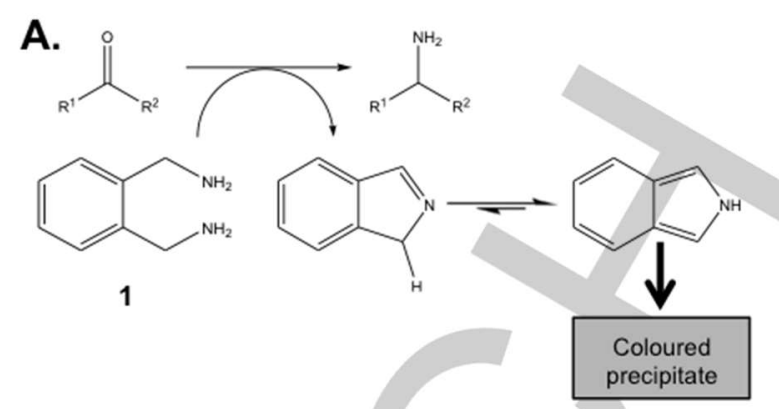

B.

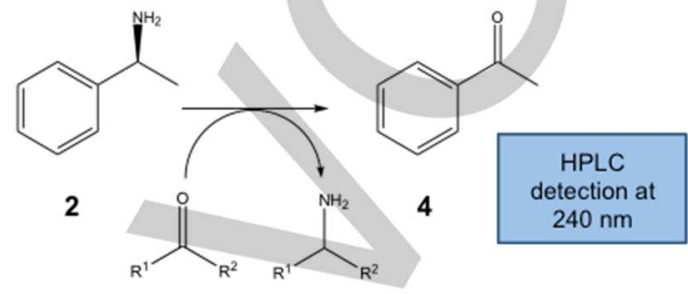

C.

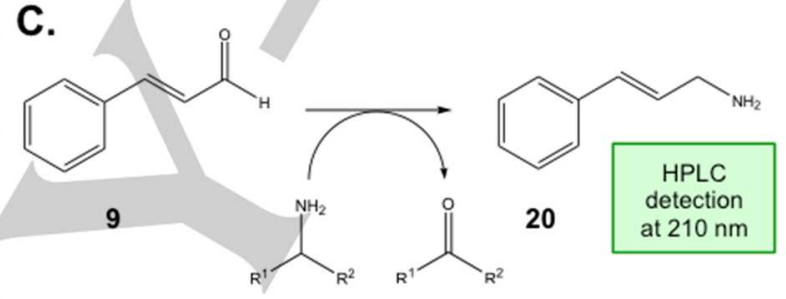
nature, the relatively low value obtained highlights the potential need for directed evolution to improve specific activity of this enzyme towards certain substrates. Such site-specific mutations have proven extremely successful in improving the activity of TAms by several orders of magnitude, with a growing number of examples in the current literature. ${ }^{[6,8,11]}$

\section{PLC-based screening assay using cinnamaldehyde as substrate}

The ability of Ad2-TAm to utilize a range of amino donors was examined with a HPLC-based assay using cinnamaldehyde 9 as substrate in each case (Scheme 1C). Assays for each amino 
donor were carried out in triplicate, with values for vector only controls subtracted from Ad2-TAm to provide overall values. Formation of cinnamyl amine $\mathbf{2 0}$ product (detected at $210 \mathrm{~nm}$ ) was used to determine relative ability of the enzyme to accept each amino donor. Of the compounds tested, $o$-XDA 1 proved to be the most effective amino donor (Fig. 8A.). As well as being readily accepted by the enzyme,

Fig. 5. Colorimetric assay employing a selection of substrates $(5 \mathrm{mM})(A$. 3 , B. 7, C. 19, D. 9, E. 10). o-XDA (25 mM) was used as amino donor with all assays set up in potassium phosphate buffer, pH $8.0(100 \mathrm{mM})$ containing PLP (1 mM). Reaction was started by addition of His-tagged purified Ad2-TAm to a final concentration of $0.5 \mathrm{mg} / \mathrm{mL}$ (wells in column 2) and allowed to proceed for $16 \mathrm{~h}$ at $30{ }^{\circ} \mathrm{C}$ and $1200 \mathrm{rpm}$. Elution buffer $\left(50 \mathrm{mM} \mathrm{NaH}_{2} \mathrm{PO}_{4}, 300 \mathrm{mM} \mathrm{NaCl}, 250 \mathrm{mM}\right.$ imidazole, $\mathrm{pH}$ 8.0) was used as a neqative control (wells in column 1).

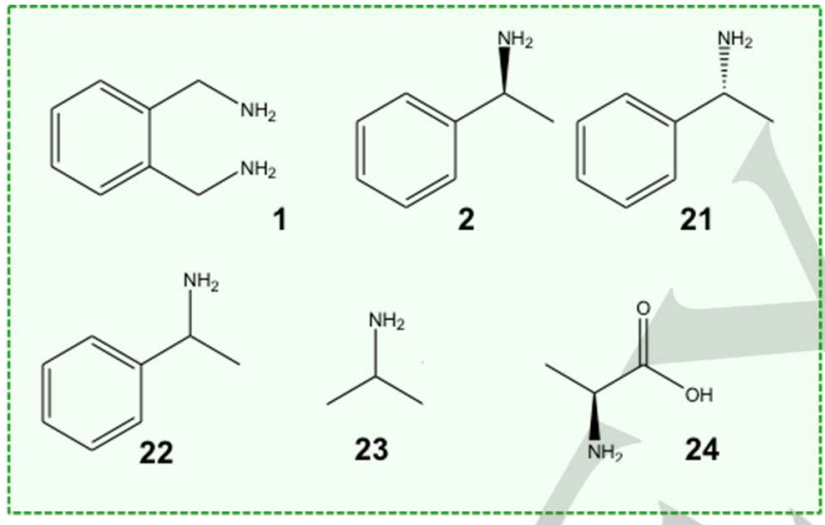

$o$-XDA also benefits from a favourable reaction equilibrium. The imine product of the initial deamination of $o-\mathrm{XDA}$ undergoes spontaneous tautomerization to form an aromatic isoindole. This effectively removes one of the products from the reaction mixture, allowing the equilibrium of the reaction to shift towards further product formation. ${ }^{[26]}$ Recently this work has been developed aminoaldehydes can dimerize or cyclize following transamination. ${ }^{[7]}$ This has been shown to substantially reduce product inhibition, which can present significant problems for TAm-catalyzed reactions and have a negative impact on conversion yield. $^{[27-29]}$

Varying the amino donor also reveals the enantiopreference of Ad2-TAm. The relative ability of Ad2-TAm to accept (S)-MBA 2 (vs. o-XDA at 100\%) as an amino donor was $89 \%$. Comparing this value with its ability to accept the $(R)$-enantiomer of MBA $21(17 \%)$ and a racemic mixture 22 of the two isomers (52\%), clearly shows Ad2-TAm to be an $(S)$-selective enzyme (Fig. 8A.).

Fig. 8A. shows the smaller amino donors isopropylamine 23 (IPAm) and Lalanine $\mathbf{2 4}$ to be less readily accepted by Ad2-TAm as amino donors, although some conversion was still observed. 


\section{Characterisation of the catalytic ability of Ad2-TAm using different reaction parameters}

Using a HPLC-based screening assay with $(S)$-MBA as amino donor and benzaldehyde as amino acceptor, the catalytic ability of Ad2-TAm was determined over a range of temperatures and $\mathrm{pH}$ (Fig. 8B. and $\mathbf{C}$ respectively). As expected with a halotolerant bacterial enzyme, Ad2-TAm displayed a largely mesophilic profile in terms of a temperature optimum of $30^{\circ} \mathrm{C}$, as has been observed with other bacterial TAms. ${ }^{[9]}$ Despite optimum conversion at $\mathrm{pH}$ 9.0, Ad2-TAm continued to bring about a relatively high level of conversion from $\mathrm{pH} 8.0$ to 11.0 . This is consistent with limited published data on TAms from halotolerant bacteria. ${ }^{[22]}$ Many halotolerant organisms are also alkalotolerant, owing to the environments in which they are often found. High-salt environments are often alkaline in nature, such as soda lakes, resulting in the emergence of haloalkalotolerant microorganisms.

Ad2-TAm showed an ability to convert substrate in organic solvents, with $67 \%$ conversion in $10 \%$ dimethylformamide (DMF). Previous use of DMF as a solvent

Fig. 6. Amino donors screened with assay B (using cinnamaldehyde as amino acceptor and HPLC detection of cinnamyl amine at $210 \mathrm{~nm}$ ).

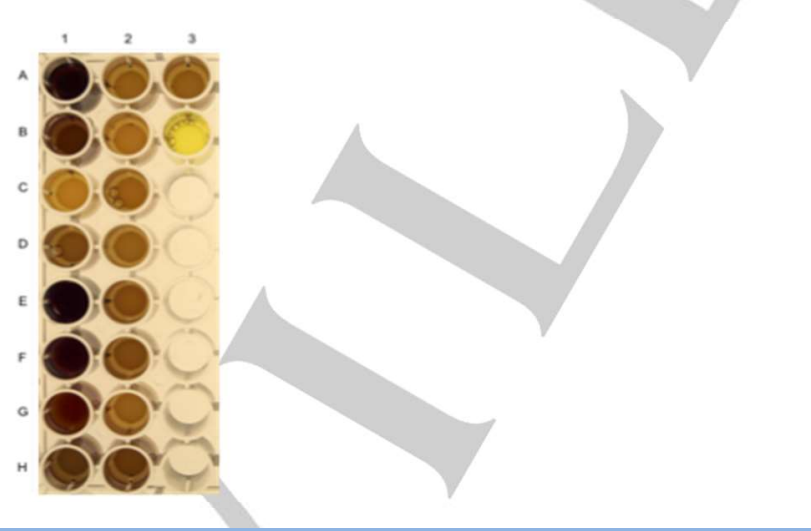

Fig. 7. Colorimetric assay employing a number of substrates $(5 \mathrm{mM})(\mathrm{A} 1$ 3, B1. 5, C1. 19, D1. 17, E1. 7, F1. 6, G1. 9, H1. 10, A2. 13, B2. 12, C2 14, D2. 15, E2. 18, F2. 16, G2. 11, H2. 8). o-XDA (25 mM) was used as amino donor with all assays set up in potassium phosphate buffer, $\mathrm{pH} 8.0$ $(100 \mathrm{mM})$, containing PLP $(1 \mathrm{mM})$. Reaction was started by addition of Ad2-TAm cell-free extract to a final concentration of $20 \mathrm{mg} / \mathrm{mL}$ and allowed to proceed for $30 \mathrm{~min}$ at $30^{\circ} \mathrm{C}$ and $1200 \mathrm{rpm}$. DMSO in place of substrate was used as a control (well A3). Empty pET28a+ vector cloned into E. coli BL21 DE3 cells was used as an additional control with no substrate (well B3). has been applied to TAmcatalyzed reactions in the production of pharmaceuticals. Its addition as a co-solvent improved both the reaction process and substrate loading in the production of an intermediate for the pro-drug silodosin, used in the treatment of benign prostatic hypertrophy. ${ }^{[31]}$ With Ad2-TAm, an increase above $10 \%$ concentration of DMF led to a dramatic reduction in conversion. However, increasing 
the concentration of dimethyl sulphoxide (DMSO) from $10 \%$ to $20 \%$ led to an increase in conversion from $51 \%$ to $68 \%$. $^{[30]}$ 


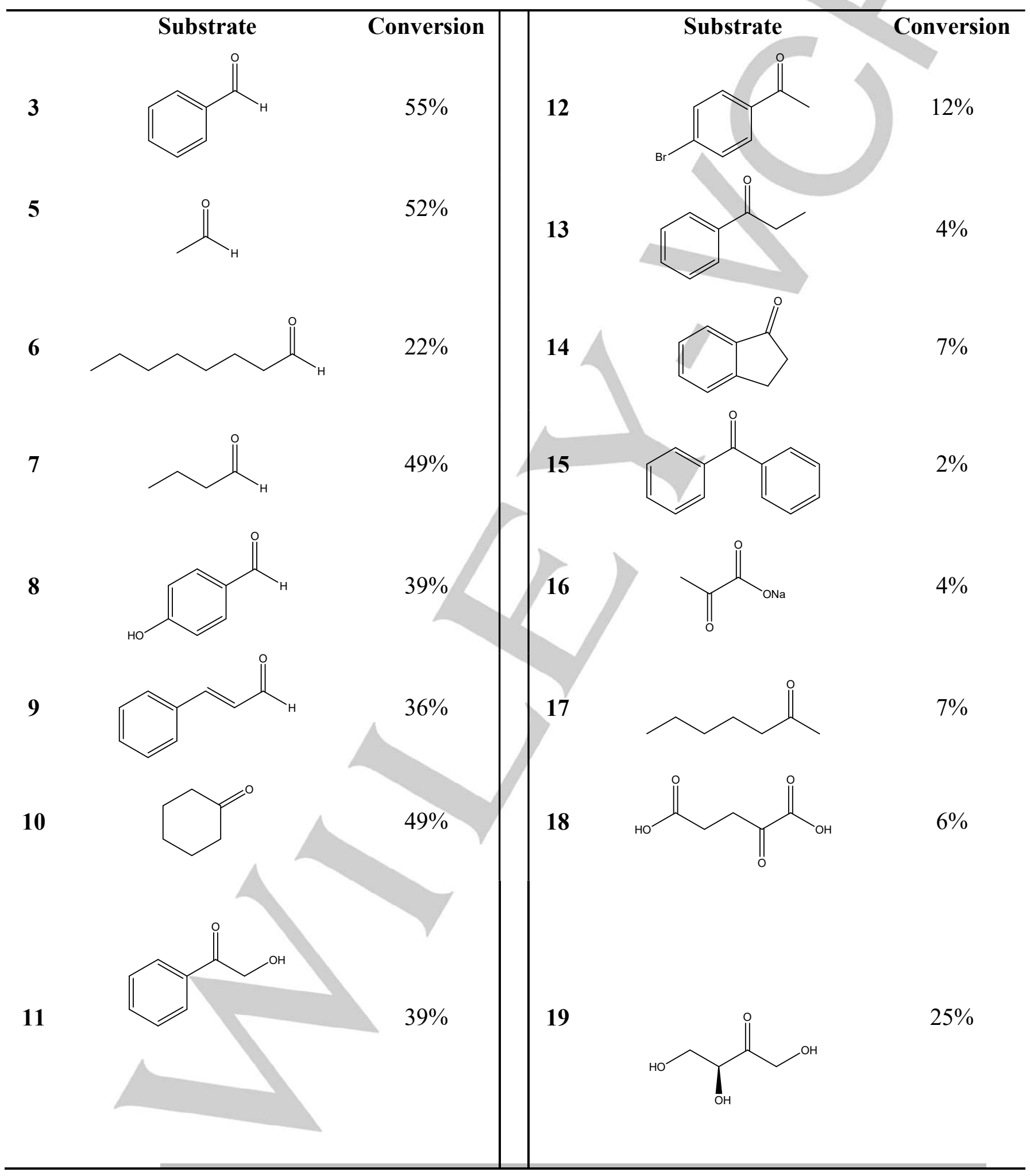


Table 1. Overall conversion for a number of substrates under the following reaction conditions: (S)-MBA (25 mM), substrate (5 mM), $\mathrm{P}$ $(1 \mathrm{mM})$, potassium phosphate buffer, $\mathrm{pH} 8.0(100 \mathrm{mM})$. Reaction was started by addition of Ad2-TAm cell-free extract to a fir concentration of $20 \mathrm{mg} / \mathrm{mL}$ and allowed to proceed for $16 \mathrm{~h}$ at $30{ }^{\circ} \mathrm{C}$ and $1200 \mathrm{rpm}$. Empty pET28a+ vector cloned into E. coli BL21 D cells was used as a negative control. All experiments were carried out in triplicate with empty vector control readings subtracted from c free extract readings. Conversions were obtained via detection of acetophenone formation at $240 \mathrm{~nm}$ and varied by $< \pm 2 \%$, with exception of acetaldehyde $(< \pm 8 \%)$.

Subsequent decrease in conversion was only seen when DMSO was increased to $30 \%$, although the enzyme continued to function well at this concentration. As many substrates for TAm-catalyzed reactions are poorly soluble, ${ }^{[6]}$ a greater amount of substrate in solution may account for the increase in conversion at $20 \%$ DMSO. Nonetheless, substrate solubility can be an important limiting factor in TAmcatalyzed reactions, ${ }^{[6]}$ and an enzyme capable of functioning at high concentrations of organic solvent could prove very valuable in chiral amine synthesis.

Ad2-TAm showed reasonable tolerance to a number of other organic solvents, showing $>10 \%$ conversion rates in methanol, ethanol and isopropanol (Fig. 8D.). Conversion quickly deteriorated upon increases in concentration of these solvents above $10 \%$. When no co-solvent was used in the reaction, an average conversion of only $14 \%$ was achieved. 
A

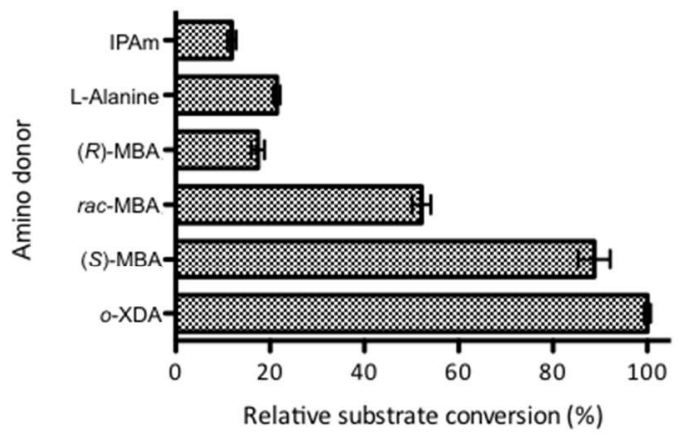

C

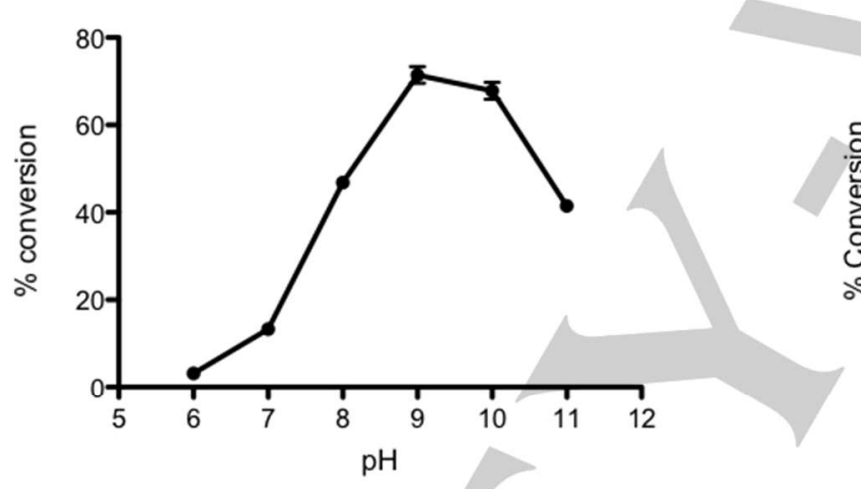

E

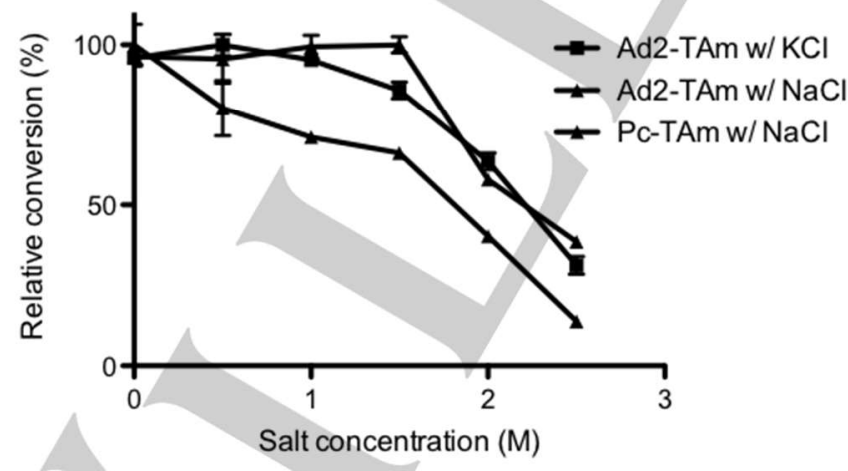

B

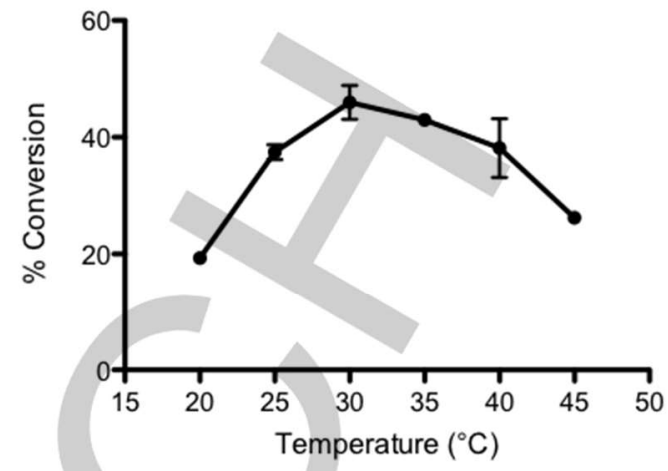

D

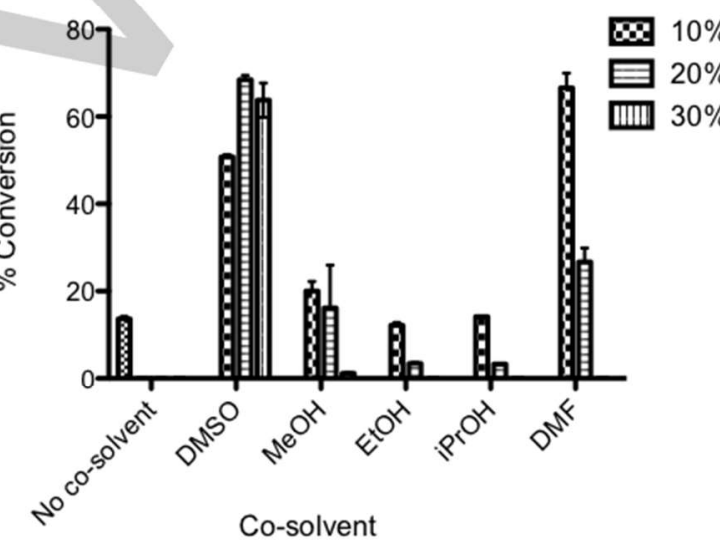

Fig. 8A. The effect of different amino donors on the amination of cinnamaldehyde, shown as relative substrate conversion based on the detection of cinnamyl amine formation at $210 \mathrm{~nm}$. B-E. The effect of various parameters on the amination of benzaldehyde using Ad2TAm cell-free extract, using (S)-MBA as amino donor with acetophenone formation measured at $240 \mathrm{~nm}$. Plotted values are the mean of triplicate measurements, with error bars representing \pm standard deviation in each case.

The effect of varying salt concentrations on conversion was also examined, with Ad2-TAm displaying a high level of tolerance to both $\mathrm{NaCl}$ and $\mathrm{KCl}$ (Fig. 8E.). Acetophenone was formed with $54 \%$ conversion at $1.5 \mathrm{M} \mathrm{NaCl}$. Maximum 
conversion with $\mathrm{KCl}$ was seen at $0.5 \mathrm{M}$, with $55 \%$ conversion, with $>85 \%$ of this conversion still achieved at $1.5 \mathrm{M} \mathrm{KCl}$.

Halotolerance of Ad2-TAm was assessed against the commercially available $\omega$ TAm from Penicillium chrysogenum (Pc-TAm), a mesophile (Fig. 8E.). Ad2-Tam displayed much greater tolerance to increasing concentrations of salt than Pc-TAm, with maximum conversion observed at $1.5 \mathrm{M} \mathrm{NaCl}$ vs. only $66 \%$ relative conversion for Pc-TAm at this salinity (Fig. 8E.). As $\mathrm{NaCl}$ concentration was increased further, Ad2-TAm continued to produce significantly greater conversions than the fungal enzyme. These observations are all the more impressive in view of the osmotic tolerance exhibited by fungi ${ }^{[32-36]}$ such as $P$. chrysogenum. Moderately halophilic bacteria are adapted to high salt environments via a process known as 'salting out'. Efflux pumps remove $\mathrm{NaCl}$ from within the cell, which is replaced by compatible solutes such as zwitterions or sugars in order to maintain the osmotic balance with outside the cell. ${ }^{[37-39]}$ As such, their intracellular machinery does not possess the specific adaptations to high salinities exhibited by their haloarchaeal counterparts. These observations demonstrate the Ad2-TAm enzyme to be at the very least moderately halotolerant. The ability of this enzyme to function at increased salinity represents a promising addition to a currently scarce list of successes of TAms from halotolerant organisms.

Using (S)-MBA 2 as amino donor and benzaldehyde $\mathbf{3}$ as substrate, the original $200 \mu \mathrm{L}$ reaction volume was increased to $100 \mathrm{~mL}$, representing a $500 \times$ increase in total reaction volume. A decrease from $55 \%$ to $30 \%$ conversion was observed on volume increase, suggesting further improvements would be needed to the process in order to apply Ad2-TAm as a biocatalyst on an industrial scale. Future work for upscale is ongoing, with details of product recovery, isolation and optical purity required before the suitability of Ad2-TAm can be fully assessed as a candidate for industrial applications. Increasing substrate loading beyond the $5 \mathrm{mM}$ concentration used in this investigation is also a factor for further investigation. Despite these areas which require further work, the conversion seen in organic solvents, at high salt, and over a range of $\mathrm{pH}$ values, suggests Ad2-TAm has potential as a candidate for application in industrial processes. 


\section{Conclusions}

Limited substrate scope of current TAms and their inability to tolerate challenging reaction conditions has driven the search for new enzymes. We have reported the cloning and expression of a novel biocatalyst from an extreme hypersaline environment, formed over 220 million years ago. Enzyme Ad2-TAm possessed a broad substrate range and an ability to function under challenging parameters. As well as accepting both aliphatic and aromatic ketones and aldehydes, Ad2-TAm also demonstrated an ability to convert substrate over a range of $\mathrm{pH}$ values, as well as in organic solvent and at elevated salinities. These characteristics highlight the potential benefits of employing enzymes from halotolerant organisms in biocatalysis, including a capacity to aminate substrates under conditions which are often too challenging for mesophilic enzymes. These observations also highlight Ad2-TAm as a potential biocatalyst for chiral amine synthesis in the pharmaceutical industry. 


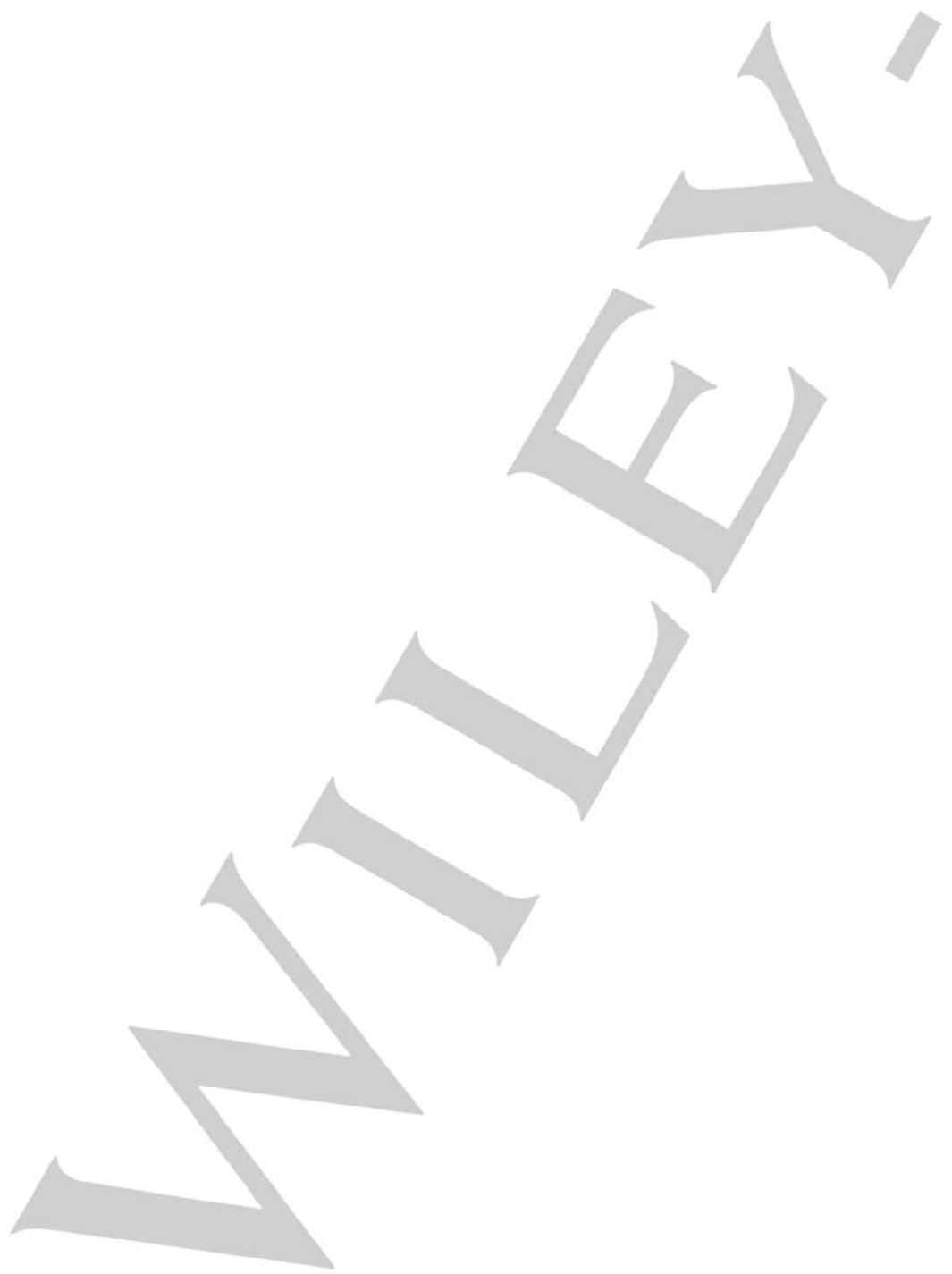

